\title{
Pengolahan Citra Satelit dalam Deteksi Alih Fungsi Hutan Pada Daerah Aliran Sungai Arut Kabupaten Kotawaringin Barat Provinsi Kalimantan Tengah Berbasis Sistem Informasi Geografis
}

\author{
Gregorius Anung Hanindito ${ }^{1}$ \\ ${ }^{1}$ Dosen Tetap Fakultas Teknik, Universitas Antakusuma \\ Jalan Iskandar 63 Pangkalan Bun Kalimantan Tengah e-mail: gregory.anung@ gmail.com)
}

\begin{abstract}
Kotawaringin Barat Regency is located in Central Borneo. Geographically, three big rivers flow through Kotawaringin Barat Regency: Kumai River, Lamandau River, and Arut River. As the density has increased, river triggers new problem as the result of infrastructure development and agricultural and plantation expansion. Based on that issue, this research is aimed to observe the land cover change of Arut River watershed, in Kotawaringin Barat Regency, Central Borneo. Remote Sensing method is used aligned with Geographic Information System. Data are taken from Landsat Satellite image in the year of 1996, 2010, and 2016. The data are classified by the appearance using Supervised Classification method and analyzed using Intersection technique. The limitation of the study is focusing only on the forest and the plantation appearance. As the output, this research yields a land cover change map from forest to plantation from 1996-2016 and the changing pattern of the forest and plantation total area in this time period.

Keywords: Geographic Information System, intersection, Landsat, remote sensing, supervised classification
\end{abstract}

Intisari- Kabupaten Kotawaringin Barat merupakan salah satu kabupaten di wilayah Kalimantan Tengah yang secara geografis dialiri oleh 3 (tiga) sungai besar yakni: Sungai Kumai, Sungai Lamandau dan Sungai Arut. Seiring berjalannya waktu dan bertambahnya kepadatan penduduk, keberadaan sungai memberikan permasalahan baru akibat pembangunan dan ekspansi pertanian dan perkebunan. Mengacu pada permasalahan tersebut, maka penelitian ini dilakukan untuk mengamati tingkat alih fungsi lahan (land cover change) yang terjadi di daerah aliran sungai Arut, Kecamatan Arut Selatan, Kabupaten Kotawaringin Barat. Penelitian ini dilakukan dengan metode penginderaan jauh dan sistem informasi geografis. Data yang digunakan dalam metode ini ialah data citra satelit Landsat pada tahun 1996, 2010, dan 2016. Ketiga data tersebut diklasifikasikan sesuai dengan kenampakannya dengan metode supervised classification dan dianalisis dengan teknik intersection. Pembatasan alih fungsi dalam penelitian ini hanya dilakukan pada kenampakan hutan dan perkebunan saja. Dalam penelitian ini dihasilkan peta perubahan alih fungsi hutan menjadi perkebunan dalam periode waktu 1996-2016. Penelitian ini juga menghasilkan pola perubahan luas hutan dan perkebunan selama periode waktu tersebut.

Kata Kunci: intersection, Landsat, penginderaan jauh, sistem informasi geografis, supervised classification

\section{PENDAHULUAN}

Kehidupan masyarakat di Pulau Kalimantan sangat bergantung pada keberadaan sungai. Bagi masyarakat setempat, sungai dimanfaatkan sebagai sarana kebutuhan sehari-hari, dengan kata lain sungai merupakan salah satu objek vital perkembangan perekonomian, perdagangan, pertanian perkebunan, dan pembangunan [1]. Di sisi lain, seiring dengan bertambahnya jumlah kepadatan penduduk dan tingkat pembangunan yang semakin meluas menimbulkan permasalahan baru. Hal ini terjadi akibat adanya aktivitas perambahan hutan dan perubahan lahan menjadi lahan pertanian, perkebunan, dan permukiman [2]. Seperti halnya Pulau Kalimantan secara umum, permasalahan serupa juga terjadi di wilayah Kabupaten Kotawaringin Barat khususnya di sekitar daerah aliran sungai Arut Kecamatan Arut Selatan.

Kotawaringin Barat merupakan salah satu kabupaten di wilayah Provinsi Kalimantan Tengah yang berpusat di kota Pangkalan Bun yang ditetapkan berdasarkan UndangUndang Nomor 27 Tahun 1959 tentang Pembentukan Daerah Tingkat II di Kalimantan [3]. Secara geografis, kabupaten ini dialiri oleh 3 (tiga) buah sungai besar antara lain: Sungai Kumai, Sungai Lamandau, dan Sungai Arut [4]. Seperti halnya sungai-sungai lain di Pulau Kalimantan, sungai Arut yang melintasi ibukota Kabupaten Kotawaringin Barat ini sangat lekat dengan kehidupan masyarakat setempat dalam memberikan andil sebagai sarana perekonomian, transportasi, sosial dan budaya. Saat ini, kondisi tersebut telah berubah, sungai Arut yang dahulu menjadi objek vital bagi masyarakat Kotawaringin Barat, saat ini menimbulkan berbagai persoalan, diantaranya: 
pendangkalan debit air yang disebabkan oleh sodetan yang diperuntukan bagi pengairan lahan pertanian dan perkebunan [5].

Mengacu pada permasalahan tersebut di atas, maka penelitian ini memanfaatkan citra satelit Landsat untuk mengetahui besar perubahan tutupan lahan khususnya perkebunan di sekitar daerah aliran sungai Arut, Kecamatan Arut Selatan, Kabupaten Kotawaringin Barat, Provinsi Kalimantan Tengah dalam kurun waktu 19962016. Untuk mengetahui perubahan tutupan lahan perkebunan tersebut diperlukan data mengenai tutupan lahan dengan akurasi yang tinggi. Pengumpulan data perlu dilakukan secara berkala dengan memanfaatkan teknologi dan informasi yang ada. Teknologi dan informasi yang dapat dimanfaatkan untuk memperoleh data guna mengetahui perubahan lahan adalah Teknologi Penginderaan Jauh dan Sistem Informasi Geografis (SIG) [6].

Berdasarkan pengolahan data dengan menggunakan Teknologi Penginderaan Jauh dan Sistem Informasi Geografis (SIG) maka diperoleh pola dan besaran perubahan tutupan lahan pada studi area daerah aliran sungai Arut, Kecamatan Arut Selatan, Kabupaten Kotawaringin Barat.

Penelitian ini bertujuan untuk mengetahui tingkat perubahan tutupan lahan (land cover change) khususnya perkebunan yang terjadi di sekitar Daerah Aliran sungai Arut, Kabupaten Kotawaringin Barat melalui proses pengolahan data citra satelit Landsat dan sistem informasi geografis.

\section{Tinjauan Pustaka}

\section{A. Penginderaan Jauh}

Penginderaan Jauh merupakan ilmu yang digunakan untuk mendapatkan informasi objek, luas area, atau bahkan fenomena alamiah melalui suatu analisis. Pengindraan jauh memanfaatkan perangkat tertentu (sensor dan platform) tanpa adanya kontak langsung dengan objek. Metode ini paling sering digunakan karena selain dapat mencakup wilayah studi yang relatif luas. Metode ini juga dapat memberikan gambaran unsur-unsur spasial yang komprehensif dengan bentuk geometri yang relatif baik [7].
Dalam segi peralatan, penginderaan jauh dapat dilakukan dengan memanfaatkan satelit maupun pesawat udara yang dapat mengorbit dan melintas di permukaan bumi. Teknologi penginderaan jauh memiliki kesamaan satu sama lain, namun yang membedakan adalah ketinggian dan stabilitas peralatan penginderaan jauh tersebut.

Berdasarkan ketinggiannya, program satelit dapat dibedakan menjadi dua kelas yakni:

1) Satelit yang mengorbit di ketinggian geostationer permukaan bumi. Pada kelas ini umumnya terkait pada studi cuaca dan iklim.

2) Satelit yang mengorbit relatif lebih dekat dari permukaan bumi. Pada kelas ini umumnya digunakan untuk pengamatan permukaan bumi dan oseanografi [8].

\section{B. Satelit Landsat}

Landsat merupakan satelit yang berorbit secara sirkular dan sun-syncronous (melintasi garis ekuator pada waktu yang sama) dan diluncurkan oleh Amerika Serikat. Satelit ini mempunyai periode orbit setiap 99 menit dan dapat mencapai lokasi yang sama setiap 16 hari [7].

Satelit Landsat memiliki 3 (tiga) macam instrumen pencitraan yakni antara lain:

1) RBV (Return Beam Vidicon)

Merupakan instrumen yang mengambil citra (snapshot) dari permukaan bumi sepanjang track lapangan satelit pada setiap selang waktu tertentu.

2) MSS (Multispectral Scanner)

Merupakan salah satu instrumen pada satelit Landsat yang berfungsi untuk melakukan scanning pada permukaan bumi pada jalur tertentu.

3) TM (Thematic Mapper)

Merupakan instrumen scanning yang memiliki resolusi spektral, spasial, dan radiometric [9].

\section{Sistem Informasi Geografis}

Sistem Informasi Geografis merupakan seperangkat alat berbasis komputer yang dapat digunakan untuk mengumpulkan, menyimpan, memanipulasi, menganalisis, serta menampilkan informasi yang digambarkan dalam bentuk spasial. Sistem Informasi Geografis dapat merubah data menjadi sebuah informasi, dan menyajikan informasi 
tersebut dalam berbagai format dengan tujuan untuk pengambilan keputusan [10].

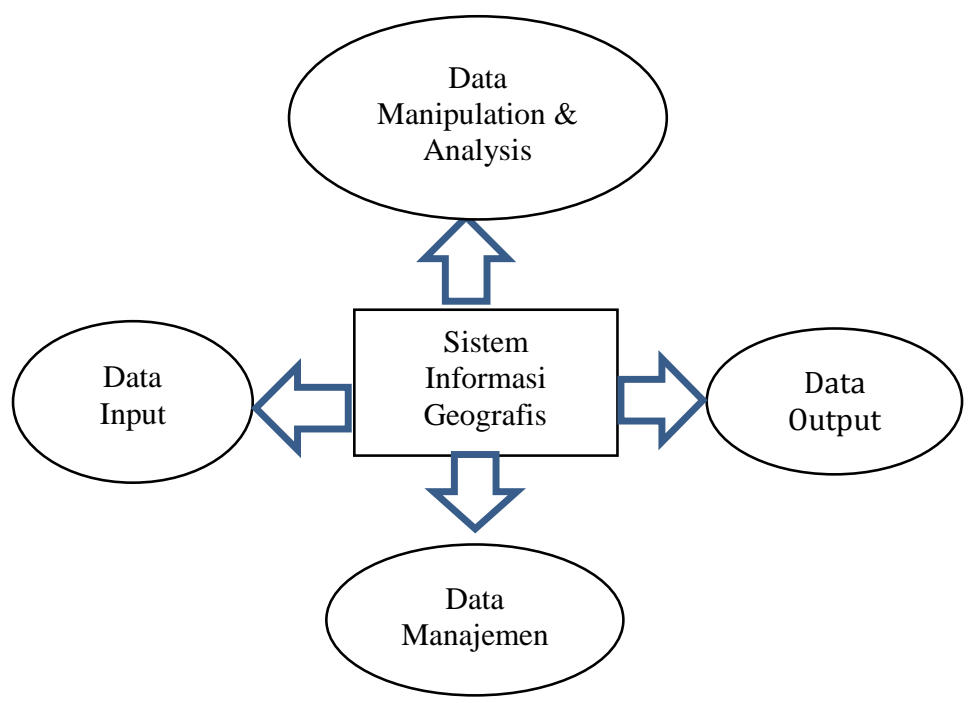

Sumber: Sistem Informasi Geografis (Perspektif Geodesi dan Geomatika), 2009

Gambar 1. Ilustrasi Sub Sistem dalam GIS

Gambar 1 menjelaskan bahwa sistem informasi geografis dapat diuraikan menjadi 4 (empat) sub sistem antara lain:

1) Data Input

Data input berfungsi untuk mengumpulkan, mempersiapkan, dan menyimpan data spasial dan atribut-atributnya yang berasal dari beberapa sumber.

2) Data Output

Data output ini berfungsi untuk menampilkan dan menghasilkan hasil pemrosesan. Data output dapat berbentuk peta, tabel, grafik, report, dll.

3) Data Manajemen

Data manajemen berfungsi untuk mengorganisasikan data spasial maupun atribut-atribut yang berada di dalamnya.

4) Data Manipulasi dan Analisis

Sub sistem ini berfungsi untuk melakukan proses analisis terhadap informasi informasi yang dihasilkan oleh Sistem Informasi Geografis [11].

\section{Perubahan Tutupan Lahan}

Perubahan tutupan lahan dapat disebabkan oleh 2 (dua) faktor yakni alam dan manusia. Faktor alam biasa terjadi dan disebabkan oleh perubahan musim dan serangan hama, sedangkan faktor manusia antara lain: deforestasi, dan pembangunan [12]. Untuk dapat mengetahui tingkat perubahan tutupan lahan, diperlukan sebuah proses yang disebut deteksi perubahan.

Deteksi perubahan merupakan proses mendeteksi perbedaan tutupan lahan pada studi area tertentu dalam interval waktu yang berbeda [13]. Deteksi perubahan tutupan lahan dapat dilakukan dengan menerapkan teknologi pengindraan jauh melalui citra satelit Landsat dan Sistem Informasi Geografis (SIG) [14].

\section{E. Penelitian Sebelumnya}

Teknik supervised Classification digunakan dalam proses pengolahan citra satelit Landsat dalam menganalisis keadaan tutupan lahan dengan studi area Kabupaten Minahasa Tenggara, Provinsi Sulawesi Utara [15].

Intersection digunakan untuk proses analisis perubahan tutupan lahan dengan melakukan overlay pada 2 (dua) buah peta yang saling bersinggungan. Analisis ini dilakukan dengan mengambil studi area di Kabupaten Minahasa Tenggara, Provinsi Sulawesi Tenggara [16]

\section{Metodologi PENELITIAN}

\section{A. Studi Area Penelitian}

Studi Area Penelitian ini adalah daerah aliran sungai Arut, Kecamatan Arut Selatan, Kabupaten Kotawaringin Barat, Provinsi Kalimantan Tengah.

\section{B. Perlengkapan dan Alat Penelitian}

Untuk menunjang penelitian ini perlengkapan yang akan digunakan antara lain:

1) Citra Satelit Landsat tahun 1996, 2010, dan 2016 Penentuan data tersebut berdasarkan pada besar tutupan awan (cloud cover) yang menaungi wilayah studi area. Ketiga data tersebut di atas memiliki tutupan awan yang relatif kecil, sebab bila data yang digunakan memiliki tutupan awan yang besar maka akan mempengaruhi tingkat akurasi klasifikasi citra satelit [17]. 
2) Data vektor administratif Kecamatan Arut Selatan, Kabupaten kotawaringin Barat, Provinsi Kalimantan Tengah

\section{Metode Penelitian}

Penelitian ini dibagi menjadi 4 (empat) tahapan yaitu sebagai berikut:

1) Pra Penelitian

2) Pengumpulan Data Citra Satelit Landsat

3) Klasifikasi Citra

4) Analisis

\section{Pra Penelitian}

Pada tahap ini dilaksanakan survei lapangan dan studi literatur terkait penelitian. Tahap studi lapangan dilaksanakan di wilayah studi area daerah aliran sungai Arut. Studi lapangan ini bertujuan untuk mengumpulkan data pendukung penelitian berupa sampel titik koordinat beserta tutupan lahan pada koordinat tersebut. Peralatan yang digunakan dalam tahap survei lapangan ini antara lain:

1) Global Positioning System (GPS)

Global Positioning System (GPS) digunakan dalam melakukan pencatatan koordinat sampel data yang selanjutnya dikomparasikan dengan koordinat pada data citra satelit.

2) Kamera Dokumentasi

Kamera dokumentasi digunakan dalam melakukan dokumentasi tutupan lahan pada studi area tersebut.

Tahap studi literatur dilakukan dengan pengumpulan referensi terkait penelitian yang dilakukan. Referensi yang dikumpulkan berupa jurnal, buku, dan media. Referensi yang terkumpul tersebut memperkuat argumentasi pada penelitian yang dilaksanakan.

\section{E. Pengumpulan Data}

Pada tahap ini dilakukan proses pengumpulan data yang diperoleh melalui citra satelit Landsat dengan periode dokumentasi tahun 1996, 2010, dan 2016. Ketiga data yang digunakan tersebut memiliki kode path 120 dan row 062 dengan ilustrasi pada Gambar 2.

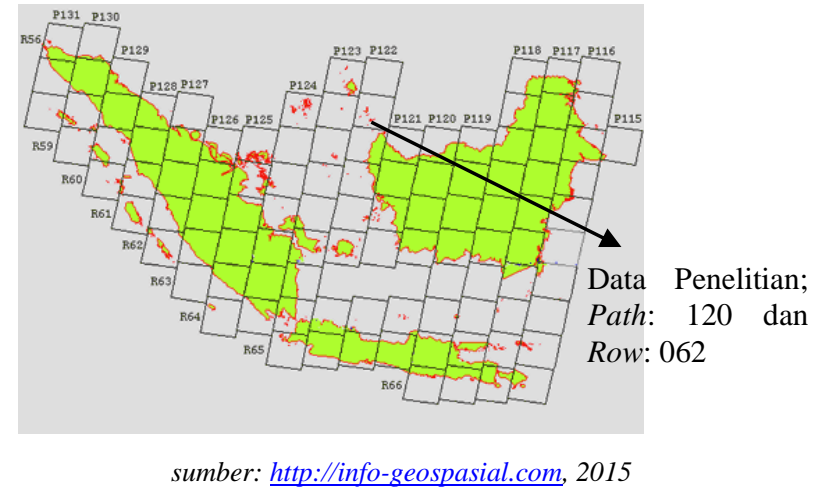

Gambar 2. Ilustrasi Path dan Row Wilayah Indonesia

Pada Gambar 3 menunjukkan data citra satelit Landsat pada area path: 120 dan row: 062.

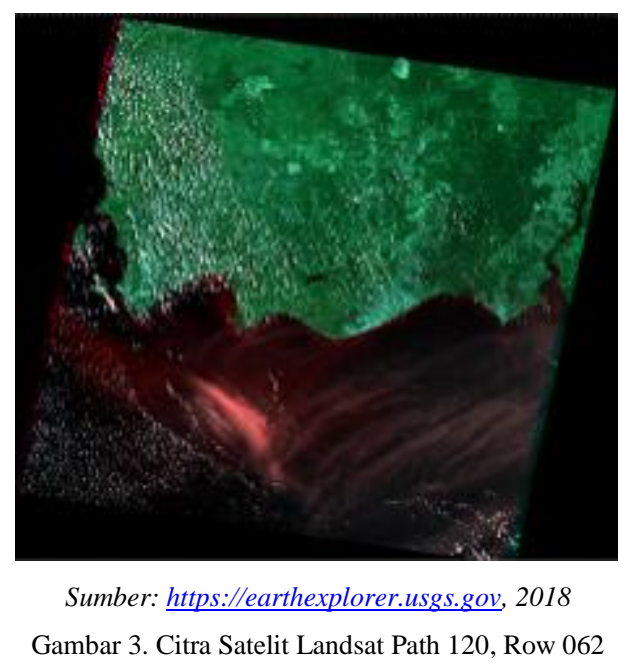

Pada tahap selanjutnya dilakukan proses cropping studi area sehingga cakupan penelitian hanya difokuskan pada wilayah yang akan diteliti. Studi area dalam penelitian ini adalah wilayah daerah aliran sungai Arut, Kecamatan Arut Selatan, Kabupaten Kotawaringin Barat, Provinsi Kalimantan Tengah yang dapat dilihat pada Gambar 4.

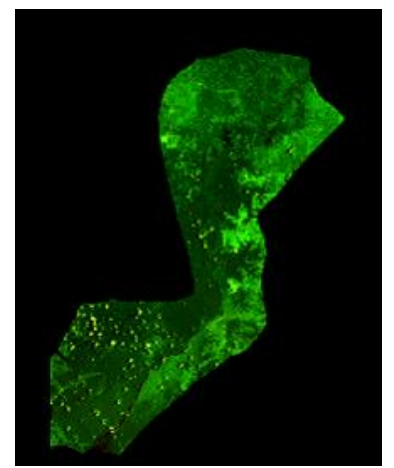

Sumber: https://earthexplorer.usgs.gov, 2018

Gambar 4. Studi area Penelitian 
Pada tahap ini seluruh data yang telah terkumpul diklasifikasikan dengan menggunakan peralatan komputer. Proses klasifikasi citra dilakukan dengan menggunakan metode Supervised Classification (klasifikasi terbimbing). Pada metode ini data latih (training site) sangat diperlukan dalam proses intepretasi citra kepada komputer. Data latih didigitasi melalui hasil yang diperoleh berdasarkan keadaan riil wilayah studi area dengan melakukan survei lapangan maupun foto udara [18]. Supervised Classification (klasifikasi terbimbing) menerapkan konsep maximum likelihood yang didasarkan pada probabilitas nilai piksel citra untuk menunjukan kelas tertentu sesuai dengan kenampakan sebenarnya [19]. Konsep maximum likelihood dapat didefinisikan sebagai berikut, apabila nilai piksel citra (X) akan dikelaskan menjadi kelas (K) jika peluang terjadinya $\mathrm{X}$ menjadi kelas $\mathrm{k}$ adalah yang terbesar dibanding dengan peluang kejadian di kelas lain dengan rumusan sebagai berikut [18].

$\mathrm{X} \rightarrow \mathrm{k}$ Jika $\mathrm{L}_{\mathrm{K}}(\mathrm{X})=\max \left\{\mathrm{L}_{1}(\mathrm{X}), \mathrm{L}_{2}(\mathrm{X}), \ldots, \mathrm{L}_{\mathrm{K}}(\mathrm{X}) \quad\right\} \ldots \ldots \ldots$. [18]

$L_{k}(X)$ merupakan peluang kejadian nilai piksel citra $(\mathrm{X})$ diklasifikasikan menjadi kelas k [18].

\section{G. Analisis}

Pada tahap ini, data citra satelit terklasifikasi akan dianalisis dengan menggunakan metode intersection. Intersection merupakan proses penggabungan peta terklasifikasi untuk memperoleh hasil overlay citra berupa wilayah yang saling bersinggungan [20].

Proses intersection dapat dilihat pada Gambar 5 berikut

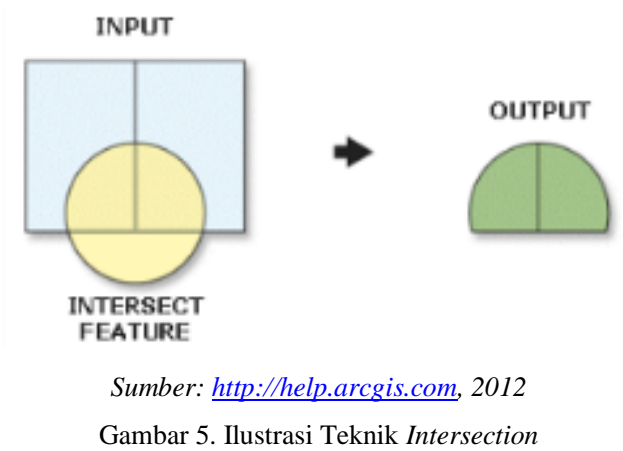

Gambar 5 merupakan ilustrasi dari teknik intersection. Pada gambar tersebut dapat terlihat bahwa 2 (buah) data yang diinputkan akan menghasilkan persinggungan antara keduanya. Hasil persinggungan tersebut akan menjadi acuan dalam deteksi perubahan tutupan lahan.

\section{H. Diagram Alir Penelitian}

Langkah penelitian yang akan dilaksanakan dapat digambarkan pada Gambar 6 berikut.

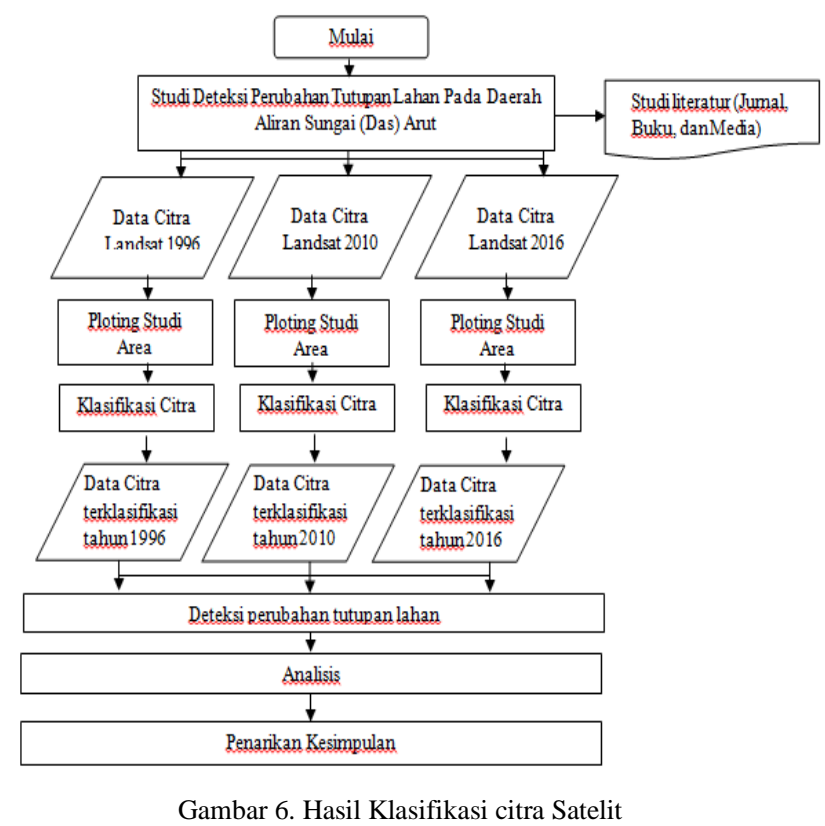

hasil dan pembahasan

\section{Hasil Klasifikasi}

Dari penelitian yang dilakukan menghasilkan 3 (tiga) buah citra satelit terklasifikasi yakni antara lain:

1) Citra tahun 1996

2) Citra tahun 2010

3) Citra tahun 2016

Hasil citra terklasifikasi tersebut dapat dilihat pada Gambar 7 berikut.
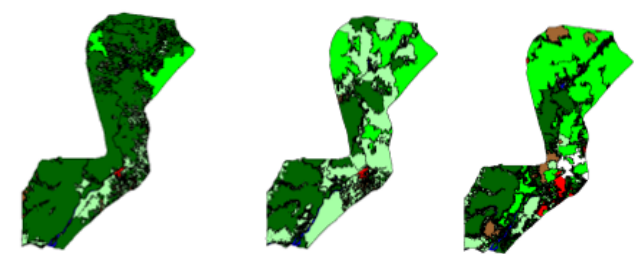

a. Tahun 1996 b. Tahun 2010 c. Tahun 2016

Gambar 7. Hasil Klasifikasi citra Satelit 
Gambar 7 merupakan hasil klasifikasi citra satelit Landsat sesuai dengan kenampakannya. Setiap kenampakan pada citra diwakili oleh warna tertentu sebagai berikut:

1) merepresentasikan kenampakan hutan

2) merepresentasikan kenampakan perkebunan

3) merepresentasikan kenampakan semak belukar

4) merepresentasikan kenampakan pemukiman

5) merepresentasikan kenampakan lahan kosong

6) merepresentasikan kenampakan tubuh air

7) $\square$ merepresentasikan kenampakan awan

\section{J. Analisis dan Pembahasan}

Sesuai dengan batasan masalah yang telah diuraikan sebelumnya, analisis perubahan tutupan lahan hanya berfokus pada perubahan tutupan area hutan menjadi area perkebuanan pada kurun waktu 1996-2016. Analisis dilakukan dengan metode intersection seperti yang telah dibahas pada bagian sebelumnya. Dari hasil analisis yang dilakukan diperoleh hasil sebagai berikut:

1) Alih fungsi Hutan 1996 - 2010

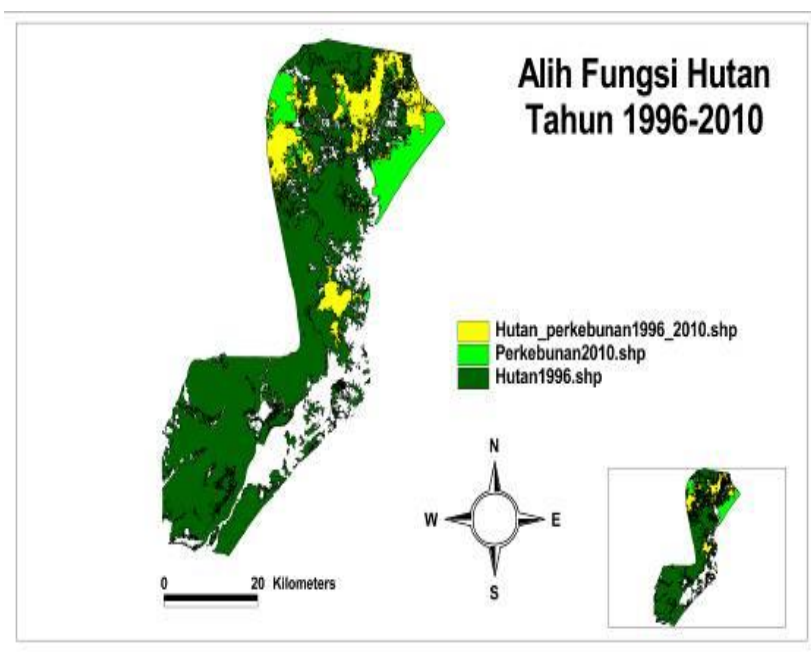

Gambar 8. Alih Fungsi Hutan tahun 1996-2010

Pada Gambar 8 menjelaskan bahwa area berwarna kuning merupakan area peralihan fungsi hutan menjadi lahan perkebunan. Pada tahun 1996 area berwarna kuning merupakan area hutan, namun hasil klasifikasi menunjukkan bahwa pada tahun 2010 area tersebut telah beralih fungsi menjadi lahan perkebunan.

2) Alih fungsi Hutan 2010-2016

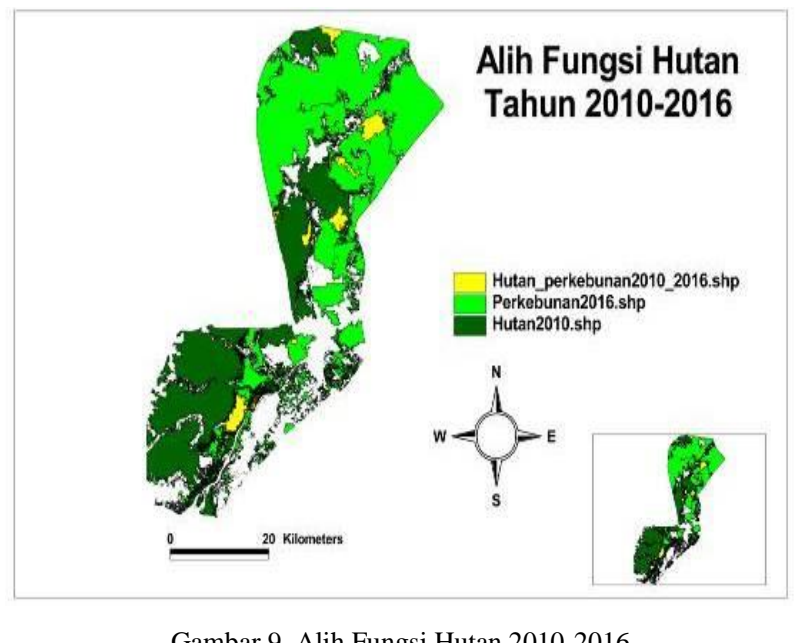

Gambar 9. Alih Fungsi Hutan 2010-2016

Pada Gambar 9 merupakan perubahan alih fungsi hutan yang terjadi dalam periode waktu 2010-2016. Gambar tersebut menjelaskan bahwa area berwarna kuning merupakan area peralihan fungsi hutan menjadi perkebunan. Pada tahun 2010 area berwarna kuning merupakan area hutan, namun hasil klasifikasi pada peta tahun 2016 area tersebut telah beralih fungsi menjadi lahan perkebunan.

3) Alih Fungsi hutan tahun 1996-2016

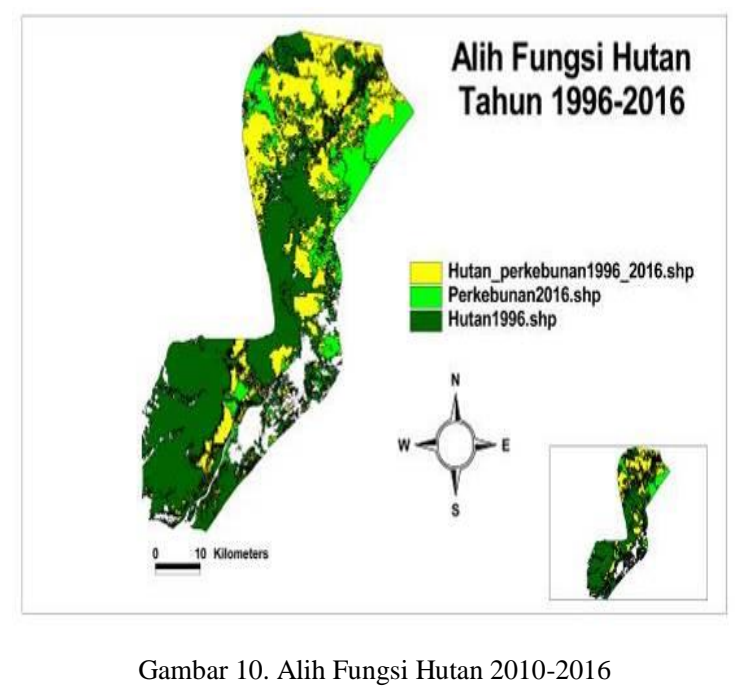

Gambar 10 menunjukkan peralihan fungsi hutan sepanjang periode 1996-2016. Pada gambar tersebut dapat dilihat bahwa area berwarna kuning merupakan area peralihan dari hutan menjadi perkebunan selama kurun waktu 20 tahun.

K. Grafik 
Dari hasil analisis serta kalkulasi yang dilakukan, maka diperoleh grafik hasil analisis luas area hutan dan perkebunan selama periode 1996-2010 yang dituangkan dalam Gambar 11 berikut.

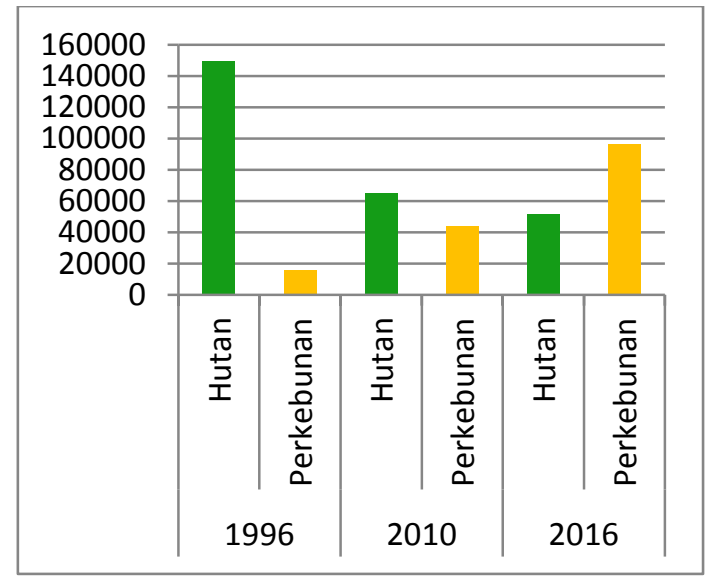

Gambar 11. Grafik Luas Hutan dan Perkebunan selama periode 1996-2016

Berdasarkan Grafik hasil analisis pada Gambar 11 di atas, luas hutan pada tahun 1996 sebesar 149.292.9 Ha, kemudian luas tersebut menurun pada tahun 2010 menjadi 65.039,27 Ha dan luas tersebut kembali menurun di tahun 2016 menjadi 51.519,2 Ha. Data grafik juga menunjukkan bahwa luas perkebunan pada tahun 1996 sebesar 15.524,13 Ha, kemudian di tahun 2010 mengalami peningkatan hingga mencapai 43.880,03 $\mathrm{Ha}$, dan kembali mengalami peningkatan sebesar 96.478,76 Ha di tahun 2016. Berdasarkan data di atas dapat dilihat bahwa selama kurun waktu 1996-2016 terjadi tingkat penurunan luas Hutan dan sebaliknya luas lahan perkebunan menjadi semakin meningkat.

Adapun rincian perbandingan luas hutan dan perkebunan pada tahun 1996, 2010 dan 2016 dapat dilihat pada Tabel 1 sebagai berikut:

Tabel 1. Luas Hutan dan Perkebuanan dalam (Ha)

\begin{tabular}{|l|l|l|l|l|l|}
\hline \multicolumn{2}{|c|}{1996} & \multicolumn{2}{c|}{2010} & \multicolumn{2}{c|}{2016} \\
\hline Hutan & Perkebunan & Hutan & Perkebunan & Hutan & \\
\hline $149.292,9$ & $15.524,13$ & $65.039,27$ & $43.880,03$ & $51.519,2$ & $96.478,76$ \\
\hline
\end{tabular}

\section{IV.KESIMPULAN DAN SARAN}

\section{A. Kesimpulan}

Berdasarkan hasil penelitian yang dilakukan melalui metode penginderaan jauh dan sistem informasi geografis, dapat disimpulkan bahwa telah terjadi alih fungsi hutan menjadi lahan perkebunan pada studi area daerah aliran

sungai Arut, Kecamatan Arut Selatan, Kabupaten kotawaringin Barat pada periode 1996-2016.

Dari hasil analisis yang dilakukan pula didapat data mengenai luas hutan dan pekebunan dalam periode waktu tersebut. Dari data tersebut, diperoleh informasi bahwa luas hutan di studi area tersebut semakin berkurang sedangkan luas perkebunan menjadi semakin bertambah.

\section{B. Saran}

Hasil penelitian ini diharapkan dapat digunakan bagi pemangku kebijakan di wilayah setempat untuk mengambil kebijakan strategis atas perubahan alih fungsi hutan menjadi lahan perkebunan yang terjadi di sekitar daerah aliran sungai Arut, Kecamatan Arut Selatan, Kabupaten Kotawaringin Barat.

\section{DAFTAR PUSTAKA}

R. P. Sari, "Pergeseran Pergerakan Angkutan Sungai di Sungai Martapura Kota Banjarmasin,” Universitas Diponegoro, 2008.

[2] A. Muchtar and N. Abdullah, "Analisis Faktor-Faktor Yang Mempengaruhi Debit Sungai Mamasa," J. Hutan dan Masy., vol 2, no. 1, pp. 174-187, 2007.

[3] PemprovKalteng, "Dari Masa ke Masa Sejarah Singkat Terbentuknya Provinsi Kalimantan Tengah,” 2013. [Online]. Available: https://kalteng.go.id/ogi/viewarticle.asp?ARTICLE_id=1609. [Accessed: 01-May-2017].

[4] BPSKobar, "Nama Sungai di Kotawaringin Barat," 2016. [Online]. Available: https://kobarkab.bps.go.id. [Accessed: 01May-2017].

[5] F. Fitriya, "Sungai Arut Saksi Sejarah Kabupaten kotawaringin Barat," Pangkalan Bun, 06-Oct-2016.

[6] B. Harjadi, "Monitoring Penutupan Lahan di DAS Grindulu dengan Metode Penginderaan jauh dan Sistem Informasi Geografis," Forum Geogr., vol. 24, no. 1, pp. 85-91, 2010.

[7] E. Prahasta, Remote Sensing. Bandung: Informatika, 2008.

[8] J. A. Richards, Remote Sensing Digital Image Analysis, 5th ed. Canberra: Springer, 2013.

[9] A. S. Thoha, "Karakteristik Citra Satelit," 2008.

[10] M. J. Bunch, T. V. Kumaran, and R. Joseph, "Using Geographic Information Systems (GIS) For Spatial Planning and Environmental Management in India: Critical Considerations," Int. J. Appl. Sci. Technol., vol. 2, no. 2, pp. 40-54, 2012.

[11] E. Prahasta, Sistem Informasi Geografis Konsep -Konsep Dasar (Perspektif Geodesi). Bandung: Informatika, 2009.

[12] N. D. Morie, "Land Use And Land Cover Changes In Harenna Forest And Surounding Area, Bale Mountains National Park, Oromia National Regional State, Ethiopia," 2007. 
[13] D. Jovanović, M. Govedarica, F. Sabo, Ž. Bugarinović, T. Beker, and M. Lauter, "Land Cover change detection by using Remote Sensing - A Case Study of Zlatibor (Serbia)," Geogr. Pannonica, vol. 19, no. 4, pp. 263-273, 2015.

[14] N. Wijaya, "Deteksi Perubahan Penggunaan Lahan Dengan

Jurnal Media Infotama Vol.15 No. 1, Februari 2019

Citra Landsat dan Sistem Informasi Geografis: Studi Kasus Wilayah Metropolitan Bandung, Indonesia," J. Geomatics Plan., vol. 2, no. 2, pp. 82-92, 2015.

[15] G. A. Hanindito, E. Sediyono, and A. Setiawan, "Analisis Pantauan Dan Klasifikasi Citra Digital Pengindraan Jauh Dengan Data Satelit Landasat Tm Melalui Teknik Supervised Classification (Studi Kasus Kabupaten Minahasa Tenggara, Provinsi Sulawesi Utara)," in Prosiding Seminar Ilmiah Nasional Komputer dan Sistem Intelijen (KOMMIT 2014), 2014, pp. 241-247.

[16] E. Sediyono, G. A. Hanindito, and A. Setiawan, "Analyzing Land Conversion in South East Minahasa, Indonesia, under Landsat Satellite Image Data using the Supervised Classification Method," in 2016 1st International Conference on Information
Technology, Information Systems and Electrical Engineering (ICITISEE), Yogyakarta, Indonesia, 2016, pp. 75-80.

[17] F. P. Utami, Y. Prasetyo, and A. Sukmono, "Analisis Spasial Perubahan Luasan Mangrove Akibat Pengaruh Limpasan Sendimentasi Tersuspensi dengan Metode Penginderaan Jauh," J. Geod. Undip, vol. 5, no. 1, pp. 305-3015, 2016.

[18] R. Mukhaiyar, "Klasifikasi Penggunaan Lahan Dari Data Remote Sensing," J. Teknol. Inf. Pendidik., vol. 2, 2010.

[19] F. S. Al-Ahmadi and A. S. Hames, "Comparison of Four Classification Methods to Extract Land Use and Land Cover from Raw Satellite Images for Some Remote Arid Areas, Kingdom of Saudi Arabia," JKAU; Earth Sci, vol. 20, pp. 167191, 2009.

[20] H. Hamdani, S. Permana, and A. Susetyaningsih, "Analisa Daerah Rawan Banjir Menggunakan Aplikasi Sistem Informasi Geografis (Studi Kasus Pulau Bangka)," J. Konstr., vol. 12, no. 1-13, 2014. 